University of Louisville

ThinkIR: The University of Louisville's Institutional Repository

College of Arts \& Sciences Senior Honors

Theses

College of Arts \& Sciences

$12-2013$

\title{
An explication of Nietzsche's views on punishment.
}

Erik Jay Hascal

University of Louisville

Follow this and additional works at: https://ir.library.louisville.edu/honors

Part of the Philosophy Commons

Recommended Citation

Hascal, Erik Jay, "An explication of Nietzsche's views on punishment." (2013). College of Arts \& Sciences Senior Honors Theses. Paper 51.

http://doi.org/10.18297/honors/51

This Senior Honors Thesis is brought to you for free and open access by the College of Arts \& Sciences at ThinkIR: The University of Louisville's Institutional Repository. It has been accepted for inclusion in College of Arts \& Sciences Senior Honors Theses by an authorized administrator of ThinkIR: The University of Louisville's Institutional Repository. This title appears here courtesy of the author, who has retained all other copyrights. For more information, please contact thinkir@louisville.edu. 
An Explication of Nietzscheôs Views on Punishment

\section{By}

\section{Erik Jay Hascal}

Submitted in partial fulfillment of the requirements

$$
\text { for Graduation (summa or magna) cum laude }
$$

and

for graduation with Honors from the Department of Philosophy (if pertinent)

$$
\text { University of Louisville }
$$

December, 2013 


\section{Introduction}

A concept that is grossly underrepresented in Nietzsche studies is his views on punishment. This underrepresentation is a shame because it is clear that Nietzsche has much to share about the topic of punishment. Nietzscheôs attention to punishment is largely found in the second treatise of his book On the Genealogy of Morals (GM) ${ }^{1}$. The GM is one of the most studied books of all Nietzscheô philosophical works, but most scholarship has focused on the first treatise (Risse, 2001). Nietzschê̂ views on punishment have not been made explicit by scholars creating a gap in Nietzsche studies. Since the GM is often studied, commentated on, and held up to academic scrutiny, then it should follow that all of the ideas in the GM, implicit or explicit, be explored. Therefore, the primary goal of this essay is to bring academic attention to the seriousness of Nietzschê̂ views on punishment.

Perhaps a reason why Nietzscheôs views on punishment in the GM are not given much attention is because he does not argue for a theory of punishment in a systemic fashion, which academic philosophy is accustomed to. Instead, Nietzschê̂ views on punishment are presented in what I shall call a critical psycho-historical (more on this below) form. For example, Nietzsche does not argue that punishment is best justified on retributive, deterrent, or restorative grounds. Instead, Nietzsche tells a psycho-historical story from genealogical perspective. He elaborates on topics (given below) which, I shall argue, make-up the crux of his views on punishment.

I shall methodically offer a close reading of the GM focusing on passages relating to punishment in order to promote the availability of Nietzscheôs views on punishment. In doing

\footnotetext{
${ }^{1}$ Quotations from Nietzsche's works make use of the following abbreviations: 'GM' for On the Genealogy of Morals, 'HAH' for Human, All Too Human, 'BGE' for Beyond Good and Evil, 'GS' for The Gay Science, 'TSZ' for Thus spoke Zarathustra, 'A' for The Antichrist, 'EH' for Ecce Homo.
} 
so, topics will emerge and bear intensive examination such as: master vs. slave morality, ressentiment, the bad conscience, the creditor/debtor relationship, guilt, etc. Where exegetical difficulties arise, I shall employ other works produced by Nietzsche in order to provide clarity and intelligibility. Additionally, I shall make use of valuable secondary sources for the purpose of making Nietzscheôs views on punishment explicit.

At the end of the essay, I shall argue that if we consider the entire corpus of Nietzscheôs philosophy, especially his views on punishment and the slave revolt in morality, that an interpretation of Nietzsche as an abolitionist toward punishment is conceivable. Since Nietzscheôs ultimate philosophical goal was to revaluate all values in order to rid modernity of a faulty and speculative Judeo-Christian ethics, the punishment practices of modernity ought to be revaluated as well. This is because a vast majority of modern Western cultureô justifications for punishment are tethered to the aforementioned Judeo-Christian ethical system. A revaluation means replacing slavish notions of justice grounded in speculative metaphysics and adopting a more naturalistic basis for punishment.

My ultimate hope by the end of this study is that I will have made Nietzscheôs views on punishment available for academic discourse. Furthermore, I will have made a significant contribution to Nietzsche studies in that I will have offered a unique interpretation of Nietzsche which shows the importance of punishment in the GM. I will have also demonstrated that Nietzschê̂ views on punishment are of value for understanding punishment as a whole.

\section{Nietzsche's Project in the GM}

In order to make Nietzscheôs views on punishment explicit in the context of the GM, it is important to first make clear what Nietzscheôs goals and methods are in the GM. The GM 
consists of three essays each committed to addressing three independent but interconnected ideas which express the development of morality throughout human history. The first, second, and third essays are 1) ñGood and Evil,ò ñGood and Bad,ò2) ñGuilt,ò Bad Conscience,ò and the Like, and 3) ñWhat is the Meaning of Ascetic Ideals.ò The GM may read as though these three essays are independent of one another and do not coalesce to make a unified theory of morality. However, in a postcard to Franz Overbeck dated January 4, 1988 Nietzsche writes:

ñfor the sake of clarity, it was necessary artificially to isolate the different roots of that complex structure that is called morality. Each of these treatises expresses a single primum mobile; a fourth and fifth are missing, as is even the most essential (áhe herd instinctổ ï for the time being, the latter had to be ignored, as too comprehensive, and the same holds for the ultimate summation of all those different elements and thus a final account of moralityò (Risse, 2001, p. 55).

This excerpt from Nietzscheôs correspondence with Overbeck indicates that Nietzsche was writing the GM as separate essays because of the complexity of each topic within each essay (Risse, 2001). However, despite Nietzscheôs structural style of breaking the GM into three essays in order to deal with the complexity of each topic individually, the postcard to Overbeck ñsuggests that Nietzsche discusses these topics separately because a joint treatment is too complicated, but that in reality, these ideas are inextricably intertwined, both with each other and with others that Nietzsche omits (Risse, 2001, p. 55). In light of Nietzscheố comments, his views on punishment, though made up of ideas scattered throughout the GM, can be reasonably believed to consist in his unified view of punishment instead of different views in various sections. For example, he discusses master and slave moralities in the first essay and the creditor debtor relationship in the second. If one was unaware of Nietzscheôs intentions to unify these ideas, then one may not treat them as unified but instead independently. This would be incorrect; the postcard to Overbeck explicitly makes Nietzscheôs intentions clear. 
Nietzsche does not propose justifications for punishment in the systematic way that contemporary academic philosophy is used to seeing; he is critical of such systems. He does not begin by postulating a reason for punishment i.e. deterrence, retribution, or restoration. Instead, Nietzsche sets his project in the GM to explore the historical situations in which the origins of morality took root. More specifically, Nietzsche is concerned not only with the origins of morality, but the value of morality itself. Nietzsche says:

ñunder what conditions did man devise these value judgments good and evil? And what value do they themselves possess? Have they hitherto hindered or furthered human prosperity? Are they a sign of distress, of impoverishment, of the degeneration of life? Or is there revealed in them, on the contrary, the plentitude, force, and will of life, its courage, certainty, future?ò(GM P: 3).

These questions posed by Nietzsche offer critical insight into what his intentions and goals are in the GM. However, Nietzsche began this project of scrutinizing morality and its value more or less in Human, All too Human (HAH).

In HAH, Nietzsche ñtaught us to be wary of origins, and to despise every account which recalls ñthe originò as the ideal moment of some essential value or truthò (White, 1994, p.63). Furthermore, HAH is where Nietzsche completely abandons any allegiances to traditional Western metaphysical claims like those found in Kantố or Platô̂ philosophies or any other forms of scholastic metaphysics. He argues that traditional metaphysics attempt to solve ontological issues of human existence as if they are timeless and universal. The methods of Metaphysician $\hat{Q}$ are to try and justify human existence without reference to anything found in existence. Nietzsche finds these methods to be utterly useless because they ignore the historical conditions of human beings. He says ñmystical explanations are considered deep. The truth is that they are not even superficialò (GS: 126). Examining the psycho-historical conditions of man, according to Nietzsche, will provide superior information to issues regarding human 
existence than traditional speculative metaphysics. For Nietzsche, traditional metaphysics beget error and self-deception, passion, and worst of all, belief in faulty systems (HAH I: 9). He says,

$\tilde{n}$ When one has disclosed these methods as the foundation of all extant religions and metaphysical systems, one has refuted them! Then that possibility still remains over, but one can do absolutely nothing with it, not to speak of letting happiness, salvation and life depend on the gossamer of such a possibility. For one could assert nothing at all of the metaphysical world except that it was a being-other, an inaccessible, incomprehensible being-other; it would be a thing with negative qualitiesò (HAH I: 9).

Metaphysical systems of morality, like those found in Christianity, Plato, and the like, fit the bill of faulty systems in that human salvation and happiness depend on obeying mediated moral imperatives from god or external forms. Moreover, the objects of value are outside of this existence. This, for Nietzsche, leads humans to ignore and deny the immediate life available to humans. Systems like Christianity are successful because they impose knowledge and truths about morality through a sense of existential guilt and shame (Risse, 2005).

While morals systems like Christianity assert that the knowledge obtained about morality must be true because it came from god, Nietzsche maintains his weariness of such knowledge. All metaphysical knowledge is ñan error in the interpretation of certain natural events, a failure of the intellectò (GS: 151). He goes on to explain that ñeven if the existence of such a world were never so well demonstrated, it is certain that knowledge of it would be the most useless of all knowledge: more useless even than knowledge of the chemical compositions of water must be to the sailor in danger of shipwreckò(HAH I: 9).

By divorcing himself from metaphysics in $\mathrm{HAH}$, Nietzsche is coming to realize his own genealogical method for explaining the origin of morality and its value, which will affect his views on the origins of punishment as well. This realization can be seen in the following passage: 


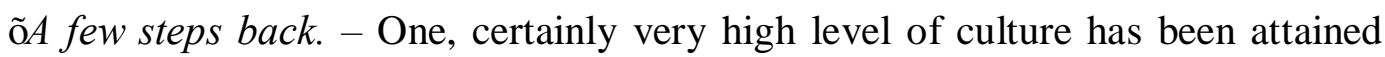
when a man emerges from superstitious and religious concepts and fears and no longer believes in angels, for example, or in original sin, and has ceased to speak of the salvation of souls: if he is at this level of liberation he now has, with the greatest exertion of mind, to overcome metaphysics. Then, however, he needs to take a retrograde step: he has to grasp the historical justification that resides in such ideas, likewise the psychological; he has to recognize that they have been most responsible for the advancement of mankind and that without such a retrograde step he will deprive himself of the best that mankind has hitherto producedò(HAH I: 20).

This is a potent idea for Nietzscheôs philosophical development. He realizes that morality and its value are not being adequately understood through faulty speculative metaphysical systems. Where he once embraced the notion of a dualistic metaphysics ï namely in The Birth of Tragedy, he has now completely discarded those methods and ideals and come to terms with his future genealogical project. Nietzsche, therefore, begins developing his methodology for grounding morality and its value in the psycho-historical conditions of humanity.

Nietzscheô project in the GM is to scrutinize not only Christian morality, but all morality and its value in accordance with his philosophical epiphanies in HAH. In doing so, Nietzsche attempts to trace the origins of morality and its value from a psycho-historical perspective in order to provide an explanation of where morality has come from and where it is going. Nietzsche wants to ñwrench us free from our established perspectives, and confound all our moral prejudiceé he returns to the ñoriginò of morality $\ddot{i}$ not to legitimate contemporary valuesé buté to pose them as a problem for the very first timeò (White, 1994, p.64). Punishment is a fundamental inquiry when talking about morality and its value. Therefore, during the course of the GM, Nietzsche is scrutinizing and questioning the foundations of morality and its value, and punishment is an important part of this discussion. I shall now move into a discussion regarding Nietzscheôs kind of naturalism and psycho-historical inquiry. His 
naturalism is important to his views on punishment because modern justifications for punishment all presuppose a slavish (more on this below) telos and fundamental moral underpinnings to which he is critical.

There is an abundance of literature written on Nietzscheô naturalism. It would be a time laborious exercise to introduce, explicate, and juxtapose even half of the interpretations offered by the most relevant commentators. Thus, for the purposes of this essay, I shall make use of Richard Schacht (2012) and Christopher Janawayôs (2007) interpretations of Nietzscheôs naturalism. I have chosen these two commentators because they closely relate to my own reading of Nietzscheôs naturalism. Before I introduce any commentators on Nietzscheôs naturalism it is only fair to let Nietzsche have first crack at explaining his task. He says ñMy task: the dehumanizing of nature and then the naturalizing of humanity after it has acquired the pure concept ónatureâ̂ (Ansell-Pearson, 1991, p. 9). Now with this in mind let us examine what Nietzscheô naturalism is and why it is relevant to his views on punishment.

Janaway characterizes Nietzscheôs naturalism as follows:

F̃ne [Nietzsche] opposes transcendent metaphysics, whether that of Plato or of Christianity or of Schopenhauer. He rejects notions of the immaterial soul, the absolutely free controlling will, or the self-transparent pure intellect, instead emphasizing the body, talking of the animal nature of human beings, and attempting to explain numerous phenomena by invoking drives, instincts, and affects which he locates in our physical, bodily existence. Human beings are to be áranslated back into natureô since otherwise we falsify their history, their psychology, and the nature of their values $\ddot{i}$ concerning all of which we must know truths, as a means to the all-important critique and eventual revaluation of valuesò (Janaway, 2007, p.34).

It is demonstrated above that Nietzsche abandons all forms of metaphysical inquiry in Human, all too Human. He becomes a kind of scientist in that he challenges us to look at ourselves 
psycho-physiologically and in a historical context $\ddot{i}$ ñwe others who thirst after reason, are determined to scrutinize our experiences as severely as a scientific experiment $̈$ hour after hour, day after dayò(GS: 319).

Nietzsche argues that humans do not possess an ámmaterial soul, an ábsolutely free controlling willô or a óself-transparent intellect.ô If humans do not possess any of the aforementioned characteristics attributed by metaphysical inquiry, which humans use to justify their specialness and separate themselves from the rest of the animal kingdom, then what is left to say about the human? Nietzsche says that what is left is the individual who only has the psychological and physiological faculties given to him by nature which are empirically justified. For Nietzsche, and anyone who takes this issue seriously, this is a profound notion and a tough pill to swallow. Part of what can be seen in Nietzscheôs naturalism is his struggle to overcome a massive cultural influence of speculative metaphysical belief and faith, and instead take a genuine and honest look at what it means to be human. He recognizes that the natural sciences do not paint a pleasant picture of human existence. However, despite the invitation extended by the natural sciences to pessimism, Nietzsche struggles to remain optimistic and affirm human existence $\ddot{i}$ this is reflected in his naturalism. In this light, according to Nietzsche, we must become scientists of ourselves. He says, ñwe, however, want to become those we are $\ddot{i}$ human beings who are new, unique, incomparable, who give themselves laws, who create themselves. To that end we must become the best learners and discoverers of everything that is lawful and necessary in the world: we must become physicists in order to be able to be creators in this senseé ò(GS: 335). Nietzscheôs linguistic artistry ought not to be conflated here with any literal interpretation of what he means when he says áve must become physicistsô Nietzsche is not proposing that we should literally engage in physics in order to achieve the level of self- 
discovery he advocates (Janaway, 2007). Instead, ñthere is a discipline and depth to the selfstudy which he finds it fruitful to see as analogous to a scientific approachò (Janaway, 2007, p. $35)$.

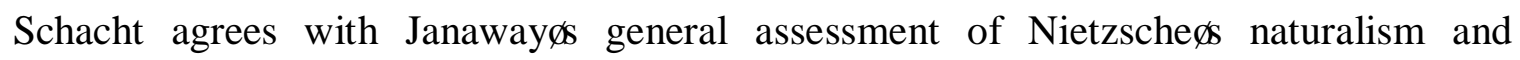
subsequently adds more perspective. Schacht says that he would amend and expand Janawayôs above statements as such:

ñNietzsche can be read as a naturalist in that he seeks explanations and interpretations of all things human that do not conflict with science, that are scientifically informed where appropriate, and that make reference to nothing beyond entirely mundane developments and transformations of our original and fundamental human animality (by ñmundaneò I mean simply to pick up on the spirit of Nietzscheôs themes of ñthis-worldlinessò and of the humble origins of everything human.)ò (Schacht, 2012, p.192).

For Nietzsche, there are no metaphysically justifiable essentials or fundamentals to existence and neither is there a telos. Instead, he is embracing what scientific inquiry says humans are $\ddot{i}$ namely, animals with instincts, drives, and desires that are in continuous fluctuation and competition in order to become fulfilled. In order for humans to be able to come to terms with what being human in a naturalistic sense means, we must be ñintellectually contentious, tough minded, unsentimental, and on guard against wishful thinking $\ddot{i}$ in our de-deified reinterpretation of human reality no less than of the world in which we find ourselvesò (Schacht, 2012, p. 195-6). We must translate man back into nature and ñcome to terms withé the terrible basic text of homo naturaò in a manner that has ñbecome hard in the training of scienceò (Schacht, 2012, p. 195). Schacht also goes on to explain that:

ñNietzsche takes as his point of departure the development he sums up in the phrase ñthe death of Godò $i ̈$ that is, the demise of the tenability not only of the Judeo-Christian God idea but also of any other sort of religiosity, metaphysically or morally envisioned different, ñhigherò and ñtruerò reality underlying or transcending the world in which we find ourselves and live our livesé His 
naturalizing reinterpretation proceeds on the suppositions that the kind of world ñthis worldò is $\ddot{i}$ ñthe world of life, nature and historyœe is the only kind of world and reality there is, with no particular configuration of it being essential or fundamental to itò (Schacht, 2012, p.193).

A note must be made here about what makes Nietzscheô naturalism unique. While he thinks the natural sciences do a great deal to explain away traditional speculative metaphysics and hone in on what being Human, all too human is, he also recognizes that the natural sciences have problems of their own. Thus, Nietzsche cannot be read as being completely trustworthy of all the data that comes from scientific inquiry. Schacht explains that ñNietzscheâs naturalismé is by no means wedded to the view that everything happens in human life and in the development and unfolding of human reality and experience can be adequately explained and fully comprehended in terms of natural-scientific or natural-scientifically modeled concepts and processesò (Schacht, 2012, p.195). For example, Nietzsche argues that the notions of cause and effect are both a strength and weakness in the natural sciences. He believes that the human existence is bound up with natural contingencies, influences, constraints, reactions, interactions and so forth which the natural sciences demonstrate to us (Schacht, 2012). However, Nietzsche doubts that the natural scientific model of causal thinking can comprehensively justify every interaction or contingency into coalescence (Schacht, 2012).

The genealogical method, for Nietzsche, is equally as crucial to his naturalism as the natural sciences. Schacht corroborates this point by saying ñNietzscheôs kind of naturalism thus is centrally concerned not only with explanations and origins but also with developmental questionsé [his] naturalism further is historically (as well as biologically) developmental; and his conception of our attained human reality is as much social and cultural as it is biological, physiological, and psychologicalò (Schacht, 2012, p.201). Therefore, Nietzscheâ naturalism is 
inclusive of both an appeal (albeit a cautious one) to what the natural sciences tell us about human existence as well as psycho-historicism grounded in a genealogical method.

\section{Master vs. Slave}

Moralityôs origins precede any kind of punishment, and especially any purposiveness or utility in punishment. It would be difficult to conceive of any purposiveness or utility in punishment without some kind of moral overtones, because without some kind of morality the question of punishment and its purpose and utility would not arise. Therefore, according to Nietzsche, we must first examine the origins of morality and its value through a psycho-historical perspective in order to understand the nature of punishment as a utility.

Nietzsche describes two basic types of moralities that arose in antiquity. These moralities can be thought of in a timeline of pre-Christianity and post-Christianity. The two types of moralities that Nietzsche names are ñmasterò and ñslaveò morality. Master and slave morality are first hinted at by Nietzsche in HAH in 1878 (Kaufmann, 2000) but later introduced and elaborated on in Beyond Good and Evil (BGE) in 1886. Finally, the ideas of master and slave morality take their full form and are fleshed out in the GM.

The GM is where we begin to see how Nietzsche understands the origins of morality and punishment. This dichotomy of moralities is a crucial point to Nietzscheôs views on punishment because, as will become clear in the paragraphs to follow, the slave revolt in morality is ultimately responsible for the punishment that modern man knows and practices ï namely punishment as a slavish utility. Punishment as a utility in the slavish sense is juxtaposed with punishment as a utility in the mastersôsense. The slaves use punishment as a way to impose guilt, shame, dishonor, etc. The masters use punishment as a way to vent their anger and power 
onto another. In this section, I shall provide an in depth account of these two kinds of moralities, and their juxtaposition to one another, in order to lay the foundation upon which Nietzscheôs views of punishment are built.

Nietzsche provides a banquet of adjectives in order to fully describe what master morality is; however, I shall only refer to descriptions which serve the purpose of correlating master and morality with the origins of punishment. The most important descriptions that Nietzsche gives us regarding master morality is that it is a morality of good and bad, not one of good and evil (BGE: 260). Anything that the masters deemed ñgoodò was beneficial or pleasing to them, and anything that was harmful to them was deemed ñbadò (Chilton, 2001). Furthermore, this morality is value-creating and self-glorifying (BGE: 260) not one of compassion or pity (Chilton, 2001). Individuals who exemplified master morality did not require moral imperatives outside or external to them. They were the creators of the moral imperatives by which they lived. Nietzsche says that:

ñé the concept of ñgoodò did not originate with those to whom ñgoodnessò was shown! Rather it was ñthe goodò themselves that is to say, the noble, powerful, high-stationed and high-minded, who felt and established themselves and their actions as good, that, of the first rank, in contradistinction to all the low, lowminded, common and plebian. It was out of this pathos of distance that they first seized the right to create values and to coin names for value: what had they to do with utilityò (GM I: 2).

Nietzsche explains that ñthe noble type of man experiences itself as determining values; it does not need approval; it judges, ñwhat is harmful to me is harmful in itselfò; it knows itself to be that which first accords honor to thingsé ò (BGE: 260). This morality came from a ñfeeling of fullness, of power that seeks to overflow, the happiness of high tension, the consciousness of wealth that would give and bestowé ò (BGE: 260). The masters, able to create and delegate their own morals and values without external influence, did not to punish their enemies or those 
who did them harm out of vengeance $i ̈$ if harm was even detected or relevant. Instead, they were ñncapable of taking oneố enemies, oneôs accidents, even oneôs misdeeds seriously for very long $\ddot{i}$ that is the sign of the strong full natures in whom there is an excess of power to form, to mild, to recuperate and to forgetò(GM II: 10).

Punishment for the masters was not expressed through revenge or retribution, but through a natural right felt among the them in order to ensure order and rank among the frnerd,ò slaves, or common peoples and make them compliant (Chilton, 2001). Nietzsche explains that

ñhroughout the greater part of human history punishment was not imposed because one held the wrong doer responsible for his deed, thus not on the presupposition that only the guilty one should be punished; rather, as parents still punish their children, from anger at some harm or injury, vented on the one who caused it $\ddot{i}$ but this anger is held in check and modified by the idea that every injury has its equivalent and can actually be pain back, even if only through the pain of the culprit.ò The masters punish because of the pleasure they receive in venting their overflowing power on the powerless; for ñthe enjoyment of violationò (GM II: 4).

Since there are no feelings of vengeance or deserts by the masters toward those who have committed infractions against the morals enjoyed by the masters, they do not feel the need to punish because one might deserve it. One who possesses master morality may not even punish at all; punishment is not felt as a necessary component to life. Nietzsche says that ñsuch a man shakes off with a single shrug many vermin that eat deep into others; here alone genuine ñove of oneâs enemiesò is possible ï supposing it to be possible at all on earth. How much reverence has a noble man for his enemies! $\mathrm{i}$ and such reverence is a bridge to loveò (GM I: 10). However, if a master punishes anyone, it would be to maintain the order and rank of human beings and all other things (Chilton, 2001). Punishment for maintaining órder and rankôamong people is part and parcel of Nietzscheôs naturalistic views. 
So, for Nietzsche, punishment in the sense of holding one personally accountable and responsible for their actions and deeds is not a valued moral imperative by the masters. Nietzsche argues that punishing for the purpose of giving someone what they deserve is a late and subtle form of human judgment and inference (Tunick, 1992). In the masterô eyes, punishing wrong doers or those who committed infractions against them was a ñwill to lifeò (Tunick, 1992). It did not serve a purpose like the hand for grasping, but a celebration of life (Chilton, 2001). Retributive, deterrent, restorative etc. justifications for punishment did not come from the masters, but instead came from the morality of the slave, which I now turn the attention.

On the opposite side of the spectrum from master morality is slave morality. It is ñone of the peace-loving herd who simply does not have the power to resistò (White, 1994, p. 65). Those who possess slave morality are without an outlet for their misery. They do not have an overflow of power like the masters and are therefore forced to relive and experience their weaknesses over and over. Nietzsche calls those who embody slave morality the violated, oppressed, suffering, un-free, uncertain of themselves, weary, but above all Nietzsche calls slave morality the morality of utility (BGE: 260). The slaves revere patience, pity, the complaisant and obliging hand, the warm heart, industry, humility, and friendliness (BGE: 260). For the slave, these qualities are honored because they make their lives more bearable due to the enduring pressures of the masters (BGE: 260). Eventually, the slaves become restless and tired of being abused by the masters, unleashing their will and power onto them, and develop what Nietzsche calls óessentiment.ô He says:

ñthe man of ressentiment is neither upright nor naïve nor honest and straightforward with himself. His soul squints; his spirit loves hiding place, secret paths and back doors, everything covert entices him as his world, his security, his 
refreshment; he understands how to keep silent, how not forget, how to wait, how to be provisionally self-deprecating and humbleò(GM I: 11).

Over time the ressentiment festers inside of the slaves and eventually they develop a collective memory of all the cruelties the masters bestowed upon them. The ressentiment and memories collected by the slaves allow them to calculate their own revenge against the masters (White, 1994), which leads to what Nietzsche calls the ñslave revolt in moralityò(GM I: 7).

In the man of ressentiment there exists what Nietzsche calls the ñbad conscience.ò Nietzsche explains that T̃hostility, cruelty, joy in persecuting, in attacking, in change, in destruction $\ddot{i}$ all this turned against the possessors of such instincts: that is the origin of the ñbad conscienceò̀ (GM II: 16). Enduring the constant celebration of cruelty by the masters without being able to outwardly discharge their ávill to powerô the slaves turned their óvill to powerô inward. Nietzsche says ñall instincts that do not discharge themselves outwardly turn inward $̈$ this is what I call the internalization of man: thus it was that man first developed what was later called his ñ soulòò (GM II: 16). One way in which Nietzsche explains the internalization of the bad conscience is through asceticism or ascetic ideals.

Asceticism, for Nietzsche, is the self-imposed denial to outwardly discharge ones instincts. Nietzsche argues that Christian asceticism is the perfect example of slavish ascetic ideals. Consider what the New Testament in the Bible says about sexual fantasies:

ñBut I unto you that whosoever looketh on a woman to lust after her hath committed adultery with her already in his heart. And if thy right eye offend thee, pluck it out, and cast it from thee: for it is profitable for thee that one of thy members should perish, and not that thy whole body should be cast into hellò (Matthew 5: 28-9, King James Version).

The message here is that if a man sees an attractive woman and experiences the natural human instinct of a sexual fantasy, then he should rip out his own eye. For Nietzsche, this kind of 
asceticism is the result of the slavish bad conscience. The slaves must fulfill their instinct to be cruel. Since they cannot outwardly discharge their instincts because of their social standing under the masters, they inwardly direct the cruelness through erecting ascetic ideals. Moreover, the instinct to be a master over something is also unfulfilled in the slaves. The ascetic ideals are a way for the slaves to feel as though they are masters $\ddot{i}$ masters of themselves. The ideals are then moralized and justified on the slavesôñomniò god. The reward for living an ascetic life is heaven and the punishment for not living ascetically is hell. Therefore, since Nietzsche has argued that the slave revolt has been victorious, it is no surprise that an ascetic codified morality of ressentiment is prevalent and punishment is the slavish tool used to perpetuate obedience to the slavish moral system. To put this in Nietzschê̂ words:

ñfor an ascetic life is a self-contradiction: here rules a ressentiment without equal, that of an insatiable instinct and power-will that wants to become master not over something in life but over life itself, over its most profound, powerful, and basic conditions; here an attempt is made to employ force to block up the wells of force; here physiological well-being itself is views askance, an especially the outwardly expression of this well-being, beauty and joy; while pleasure is felt and sought in ill-constitutedness, decay, pain, mischance, ugliness, voluntary deprivation, self-mortification, and self-flagellation, self-sacrificeò(GM III: 11).

The slave revolt in morality begins a new path for morality and its value. ñFrom the trunk of that tree of vengefulness and hatred, capable of creating ideals and reversing values, the like of which has never existed on earth beforeé (GM I: 8). Slavish ressentiment reversed the dichotomy between the slaves and the masters. As a result, the slaves created a new moral and value system by calling the masters ñevil.ò

Nietzsche explains ñthat with the Jews there begins the slave revolt in morality: that revolt which a history of two thousand years behind it and which we no longer see because it $\ddot{i}$ has been victoriousò(GM I: 7). The ñJewsò, an enslaved people who historically suffered at the 
hands of master morality, are in part responsible for reversing the dichotomy of the master/slave relationship. This reversal comes via Christianity, which ñtransvalued the power of the masters from something ñgoodò to something ñevil,òteaching man to r̃be ashamed of all his instinctsé ò (Tunick, 1992, p. 21)

The transvaluation of morals has been subtle but powerful. The term transvaluation refers to the reversal of values from good and bad to good and evil. In order for the slave revolt to be successful, the slaves must have calculated a plan to carry out this revolt. The plan is simple enough: convince the masters that their values, morals, and actions are not merely bad but evil. The slaves began creating a new set of values and morals from their vengeful eyes and hatred for the masters in order to convince the masters that their behavior toward them was evil. For example, the infliction of punishment from the masters was cruel, hard, and severe and yet celebrated which the slaves were forced to endure. The slave wanted a way out of continuously being subjected to these cruelties. Thus, the slaves began to convince the masters that punishment, among others things, of such celebrated harshness and cruelness were vices and evils to be avoided. The slavesôressentiment and desire for revenge against the masters was so potent and creative that they were able to reverse the mastersômorality and instead pose their own ónerdômorality as the virtuous. So peace, equality, pity, friendliness, humility, guilt, which are all virtues of the slave, became the new value and moral system of, not only the slaves, but now the masters as well.

How were the slaves able to convince the masters that their morality was the virtuous and the mastersômorality was evil? The answer is simple: by erecting the ideal of the Jewish god; one that is omnipotent, omnibenevolent, omniscient, and omnipresent. By erecting this ideal god, the slaves were able convince the masters that their slave morality was virtuous and ought 
to be obeyed or else the masters were evil and deserving of eternal damnation. With the arrival of Christianity, the slave revolt had sown its seeds and taken deep root in culture. Nietzsche says ñthe masters have been disposed of; the morality of the common man has woné the redemption of the human race (from áhe masters, ôthat is) is going forward; everything is visibly becoming Judaized, Christianized, mob-izedé ò(GM I: 9).

Nietzscheô psycho-historical account of this dichotomy between master and slave morality is important for his ideas of punishment because, the Western culture of modern man lives in the wake of the slave revolt. Modern man has turned his back on his instinct to punish for the enjoyment of cruelty and harshness. Instead, modern man in the West has learned to become ashamed of these instincts. The process of justifying punishment has its origins in the ressentiment and bad conscience of slave morality manifested through the slave revolt which has far reaching implications. Nietzsche brings these implications to life during the course of his discussion of the creditor and debtor relationship.

\section{Creditor vs. Debtor}

Nietzsche argues that the master/slave dichotomy is essential to understanding the origins of the modern slavish conception of punishment. In this relationship, two opposite sets of values coexisted with one another i.e. good and bad vs. good and evil, but all valuations were eventually subsumed under the good vs. evil (slave) paradigm. He applies this dichotomy to a fundamental practice of human beings $\ddot{i}$ namely rudimentary economics. Nietzsche uses the creditor/debtor relationship to establish the origin and demonstrate punishmentô transformation from a masterôs implementation to a slavish one. I shall break this section down into three parts: the first will introduce and discuss the creditor/debtor relationship as it applies to individuals and punishment, 
the second will discuss how it applies to communities and punishment, and the third will summarize why Nietzsche understands the master/slave and creditor/debtor relationships to be the cause of the origins for punishment.

1. Nietzscheôs naturalism is supportive of his account of the creditor/debtor relationship and punishment in that he does not appeal to any metaphysical claims. Instead, he grounds the legitimacy of his claims regarding this relationship in the psycho-historical/genealogical method. He explains that within the creditor/debtor relationship, human beings are engaged in a form of economics which supports survival. This relationship ñis as old as the idea of ñlegal subjectsò and in turn points back to the fundamental forms of buying, selling, barter, trade, and trafficò (GM II: 4). The idea is that ñevery damage has its equivalent and can be paid off in some wayò (Risse, 2001, p.62). The damage being that if a debtor is unable to pay his creditor what he owes, then the creditor is permitted to collect something else that the debtor owns (Risse, 2001). Nietzsche says that:

ñthe debtor made a contract with the creditor and pledged that if he should fail to repay he would substitute something else that he p̃possessed,ò something he had control over; for example, his body, his wife, his freedomé above all, however, the creditor could inflict every kind of indignity and torture upon the body of the debtor; for example cut from it as much as seemed commensurate with the size of the debté ò (GM II: 5).

Before the Christian slave revolt in human history, creditors did not punish their debtors because they held the debtors personally responsible or accountable for their deeds (more on this below). Instead, the creditor punished the debtor ñas parents still punish their children, from anger at some harm or injury, vented on the one who caused itò(GM II: 4). The anger ñis held in check and modified by the idea that every injury has its equivalent and can actually be paid back, even if only through the pain of the culpritò (GM II: 4). According to Nietzsche, humans 
possess, as a part of their ontological makeup, an instinctual awareness of the principle of equivalency. Creditors did not require statutes, sentencing guidelines, or any kind of arbitrary system in order to punish effectively albeit equivalently.

In the theater of the pre-slave revolt, punishment was not egalitarian. Individuals were not endowed with certain inalienable rights given to them by god which prohibited ñcruel and unusualò punishments. Not everyone is created equal according to Nietzsche. In fact human beings are anything but equal and should not exist as equals. There is a natural social rank order which closely resembles an aristocracy. Any system of governance among human beings, according to Nietzsche, must reflect this rank order so that humans can thrive. This is demonstrated in his account of the master/slave relationship and carried over into the punishment practices of creditors toward debtors. Furthermore, Nietzsche makes explicit his disgust for the virtue of equality by exclaiming ñyou preachers of equality, the tyrannomania of impotence clamors thus out of you for equality: your most secret ambitions to be tyrants thus shroud themselves in words of virtue. Aggrieved conceit, repressed envyé erupt from you as a flame and as the frenzy of revengeò (TSZ, p. 100). In the absence of a system committed to equality, human beings would be more likely to fulfill their life instincts instead of repress them and become ashamed of them. One of the instincts Nietzsche has in mind, which is suppressed by an ideal system of equality, is the instinct to seek pleasure through punishing oneôs debtors.

Nietzsche argues that creditors experienced great pleasures in punishing their debtors because it is a human instinct to do so, but this instinct has been suppressed and alienated by a Christian morality. The pleasure or enjoyment of punishment will be greater ñthe lower the creditor stands in the social order, and can easily appear to him as a most delicious morsel, indeed as a foretaste of high rankò(GM II: 5). In this sense, punishment was a venting of power 
upon the powerless, and the creditors were participating in the ñight of the mastersò (GM II: 5). The pleasure one experienced from inflicting cruelty was an indulgence in a Human, all too human instinctual drive to be cruel. The important point is that this kind of punishment is not one from revenge, deterrence, or restoration. It is one from a ávill to life, ôa celebration of life, a participation in the festival of cruelty, of venting oneâs power upon someone else.

A note must be made here about the pleasure derived from cruel punishment. Nietzsche is not suggesting that before the slave revolt in morality, creditors punished debtors sadistically. Nietzsche is pointing out an important aspect of what it means to be human. Humans, according to Nietzsche, are endowed with an instinct to be cruel and harsh. Considering Sigmund Freudôs ñdò here might be helpful in understanding how Nietzsche is explaining pleasure. Freud used the term ñdò to explain the psychological processes of the ñcompletely unconscious, irrational, component of personality that seeks immediate satisfaction of instinctual urges and drives; ruled by the pleasure principleò (Hockenbury \& Hockenbury, 2006, p.469). In Freudian terms, Nietzsche understands punishment for pleasure to be a function of the ñd.ò Thinking about punishment for pleasure as a function of the ñdò does not violate Nietzschê̂ naturalism because, according to Freud, the ñdò is present at birth (Hockenbury \& Hockenbury, 2006). Further, the ñIdò is empirically justified with regards to infant studies (Hockenbury \& Hockenbury, 2006). Therefore, this example of using Freudôs concept of the ñdò is on good terms with Nietzscheôs naturalistic account of the psycho-historical methodology he uses to explain the creditors instinctual drive to punish for pleasure.

Before the slave revolt, creditors indulged in this instinct when they punished a debtor who failed to repay his debt. Punishment was an outlet for the instinct to be cruel, harsh, and severe. However, the harshness and cruelness is kept in check by the notion that every debt has 
its equivalent. Therefore, pre-slave revolt, creditors did not indulge in their instinct to be cruel the same way that a serial killer or rapist indulges in his instincts to viscously bind, gag, rape, and torture his victims into submission for pleasure. In other words, one is mistaken and wrong to understand Nietzscheôs account here as an assertion that humanity consisted of brutal psychopaths to the likes of Ted Bundy, John Wayne Gacy, Jeffrey Dahmer, Dennis Rader (BTK), or even the fictional Hannibal Lecter. Instead, the instinct to be cruel is more analogous to when one desires his favorite snack and indulges in a cupcake and washes it down with a sugary soda.

On the other hand, perhaps Nietzsche is implying that punishment in the post-slave revolt era i.e. modern day is subject to an interpretation of punishment as a sadistic expression of the bad conscience. One will recall that, pre-slave revolt, the slaves were without an outlet for their instincts to be cruel and harsh. They were primarily the ones on the receiving end of such cruelness and harshness. Nietzsche argues that without an outlet, the slaves turned the instinct to be cruel inward. They subsequently created ascetic ideals i.e. do not punish cruelly from anger, justified on the belief that if they obeyed such ascetic ideals, then they would receive the prize of heaven. Once the slaves convinced the naïve masters that their ascetic ideals were handed down from the ñomniò god, to punish became synonymous with deterring one from committing sinful and evil acts or giving someone what they deserved. Punishment as modern man understands it might be elucidated as a sadistic practice perpetuating Christian ressentiment and the slavish bad conscience. The idea that every harm has its equivalent and can actually be paid back and subsequently discharged has been suppressed by the slavesôvengeful psychology. In the post slave revolt world, including modern day, punishment is a backward looking practice. We punish so that the offender knows the condemnation of his actions. We want to impress a 
memory into the offender via feelings of badness or evilness so he will not offend again. According to Nietzsche, making an offender see himself as the object of disgust and alienating him from himself is the mantra of post-slave revolt and modern punishment. So, perhaps modern Western punishment practices in this light have become worse off in that they punish from this psycho-historical framework of ressentiment and bad conscience $і ̈$ which fits the bill of a kind of righteous sadism? Or was the development of the Christian bad conscience and its subsequent perpetuation through punishment a necessary evil or as Nietzsche puts it ñhe bad conscience is an illness, there is no doubt about that, but an illness as pregnancy is an illnessò (GM II: 19)?

Nietzsche claims that the slaves, pre-slave revolt, were able to play the role of creditors and participate in these pleasurable punishment practices. It is not completely reserved for those ónoble onesôor those who symbolize master morality. This is what Nietzsche means when he alludes to áhe right of the mastersô A lower ranking individual in the social strata can be a creditor. For example, if a slave becomes a creditor to anotherô debt, then the slave is participating in the óights of the mastersôin that he is able to vent his power upon the debtor. The pleasure that the slave creditor experiences from punishing the debtor will be greater depending on the lower he ranks in the social strata. This is due to the fact that slaves are more often debtors who suffer the cruelties of the masters or creditors. Therefore, when the slave has an opportunity to be a creditor and vent his power onto someone else, he savors the experience and takes the opportunity to be as severe and cruel as possible. In other words, slavesôcruelty in punishment is always worse than a master because the slave is more calculating, vengeful, and spiteful than the master. 
2. The creditor/debtor relationship does not only apply to individuals. This relationship also applies to communities wherein the community as a whole is the creditor, and the individuals who reside within the community are the debtors. Nietzsche says thatò

ñone lives in a community, one enjoys the advantages of a community (oh what advantages! We sometimes underrate them today), one dwells protected, cared for, in peace, and trustfulness, without fear of certain injuries and hostile acts to which the man outside, the ñman without peace,ò is exposedò(GM II: 9).

Communities act as safeguards against harms to those who reside within. In order for communities to be successful at preventing or responding to harms against its members, it has to recognize a moral system and subsequently codify it. Nietzsche argues that morality is the ónerd instinctô in the individual (GS: 116). When communities codify morals into laws which can be enforced through punishing lawbreakers and deviants, the community invokes the herd instinct. ñMorality trains the individual to be a function of the herd and to ascribe value only to himself as a function of moralityò (GS: 116). Therefore, when a community punishes, it does so in order to ensure that the morals and codes of the community are obeyed. Punishment is thus necessary for the continued survival of the community.

This is a fundamental aspect of what it means to be human for Nietzsche. The instinct to seek out protections of a community and obey its codified morality seems innocuous because there are so many possible perceived benefits to be gained. However, Nietzsche argues that communal morality may turn out to be harmful especially when morality demands that one become of functionary of the communal morality; thus rendering morality immoral. For example, one may agree to communal morality but if one breaks the moral code and is punished, then he surrenders himself to being a functionary of morality in that the community might make an example of him by public humiliation, incarceration, hard labor, or any other means. Turning 
oneself into a functionary of morality, especially a Christian morality, is disgraceful for Nietzsche because it dehumanizes and affirms that human imperfection ought to be punished. I shall now make this point more clear by providing a detailed description of how communities punished pre and post-Christian slave revolt.

In pre-Christian antiquity, Nietzsche says that one resided in a community and pledged to abide by the morals and laws of that community. But what happens when one commits an infraction against the creditor (the community) and becomes a debtor? Nietzsche argues that the community will get repayment from the debtor:

ñthe lawbreaker is a debtor who has not merely failed to make good the advantages and advance payments bestowed upon him but has actually attacked his creditor: therefore he is not only deprived henceforth of all these advantages and benefits, as is fair $\ddot{i}$ he is also reminded what these benefits are really worth. The wrath of the disappointed creditor, the community, throws him back again into the savage and outlaw state against which he has hitherto been protected: it thrusts him away $\ddot{i}$ and now every kind of hostility may be vented upon himò (GM II: 9).

Exile of lawbreakers from the community is an example of a celebrated punishment. Once one has committed an infraction against the community such as failing to repay debts, he is no longer seen as worthy of reaping the advantages and benefits of the community. The only way for one to appreciate the advantages and benefits of the community is to have them stripped away. The community sees the debtor as a ñhated, disarmed, prostrated enemyé it is thus the rights of war and the victor of celebration of the vae victis in all their mercilessness and crueltyò (GM II: 9). Exile as punishment is imposed upon the debtor because the community enjoys venting its power and celebrating the exile as a victory over an enemy.

It should be noted that exile of lawbreakers and deviants is not the only punishment available to communities in this pre-Christian era. I have already suggested Nietzsche argues 
every harm or damage has its equivalent and can be paid off in some way (Risee, 2001). Therefore, it follows that communities may carry out a punishment equivalent to the harm or damage inflicted by the debtor. However, the community, at this point in time, does not seek to impose guilt, shame, dishonor etc. onto the lawbreaker. It enforces its laws only to receive equal recompense for the damage of the debtor.

Nietzsche paints a picture in the GM of a community who is able to evolve into one that no longer punishes. He says that as a communityô ñpower increases, a community ceases to take the individualôs transgressions so seriously, because they can no longer be considered as dangerous and destructive to the whole as they were formerlyò (GM II: 10). Nietzsche is purposing that absent any slavish moral systems directing punishment through utility, like that of Christianity, communities may become stronger in that punishment eventually loses its value. Nietzsche argues that in these evolved communities, every infraction still has its equivalent, but these equivalencies are not sought after through anger or pleasure derived from inflicting cruelty onto the debtor. Therefore, punishment as means for communities venting their anger and power onto debtors becomes obsolete and no longer required. In other words:

ñA compromise with the anger of those directly injured by the criminal; an effort to localize the affair and to prevent it from causing any further, let alone a general, disturbance; attempts to discover equivalents and to settle the whole matter (compositio); above all, the increasingly definite will to treat every crime as in some sense dischargeable, and thus at least to a certain extent to isolate the criminal and his deed from one another $\ddot{i}$ these traits become more and more clearly visible as the penal law evolvesò(GM II: 10).

How foreign this must sound to contemporary ears: the idea that punishment, as we know it, is no longer a part of life. How could it be possible that a community becomes so evolved that when an infraction is committed by an individual against the community, that individual goes unpunished? Nietzsche has answer to this question. He says: 
ñthe ñcreditorò always becomes more humane to the extent that he has grown richer; finally, how much injury he can endure without suffering form it become the actual measure of his wealth. It is not unthinkable that a society might attain such a consciousness of power that it could allow itself the noblest luxury possible to it $\ddot{i}$ letting those who harm it go unpunished. ñWhat are my parasites to me?ò it might say. ñMay they live and prosper: I am strong enough for that!ò (GM II: 10).

Consider another passage by Nietzsche expressed five years before in the GS:

ñNew Caution - Let us stop thinking so much about punishment, reproaching, and improving others! We rarely change an individual, and if we should succeed for once, something may have also been accomplished, unnoticed: we may have been changed by him. Let us rather see to it that our influence on all that is yet to come balances and outweighs his influence. Let us not contend in a direct fight $\ddot{i}$ and that is what all reproaching, punishing, and attempts to improve others amount to. Let us rather raise ourselves that much higher. Let us color our own example ever more brilliantly. Let our brilliance make them look dark. No, Let us not become darker ourselves on their account, like all those who punish others and feel dissatisfied. Let us sooner step aside. Let us look away (GS: 321).

Nietzsche is challenging us to think outside of our modern views of punishment. He suggests that punishment for reproaching and improving others is not how communities become more self-confident and strong; the opposite is true. We think in terms of slave morality in that we hold agents accountable for their infractions, as if they could have acted otherwise, and impose punishment upon them with the justification of retribution, deterrence, or restoration etc. Why should we have to revert to such justifications? According to Nietzsche, it is because the slave revolt in morality has been victorious and now it is inconceivable that we let infractions go unpunished. However, before the slave revolt, a strong and self-confident community had the capacity to overcome punishment. Nietzsche says, ñThis self- overcoming of justice: one knows the beautiful name it has given itself $\ddot{i}$ mercy; it goes without saying that mercy remains the privilege of the most powerful man, or better, his ï beyond the lawò(GM II: 10). 
Walter Kaufmann ${ }^{2}$ includes a footnote directing the attention to an excerpt from one of Nietzscheô books entitled The Dawn. The excerpt is important because it corroborates Nietzscheô idea that communities, pre-slave revolt, had the capacity to overcome punishment. Nietzsche says,

ñLet us eliminate the concept of sin from the world $\ddot{i}$ and let us soon dispatch the concept of punishment after it! May the exiled monsters live somewhere else henceforth and not among men $\ddot{i}$ if they insist on living and will not perish of disgust with themselves!...Shouldnâ we be mature enough yet for the opposite view? Shouldnâ we be able to say yet: every óguiltyôperson is sick? ï No, the hour for that has not yet come. As the physicians are lacking above allé as yet no thinker has had the courage of measuring the health of a society and of individuals according to how many parasites they can standò (GM II: 11, n. 2).

This passage expresses a powerful notion of overcoming sin and punishment. Communities and their members ought to evolve to a level of self-confidence and strength in order to not feel the need to punish lawbreakers due to their sinfulness. However, Nietzsche claims that the ónour for this has not yet comeôdue in part to the perpetuation of óessentimentôvia the Judeo-Christian value system extending to modernity.

The Christian slave revolt transformed punishment from a celebration and indulgence in human instincts into a tool for imposing guilt, shame, or dishonor onto the punished. No longer is cruelty in punishment celebrated as a óvill to lifeô a festival enjoyed as áhe right of the mastersô or a sign of power (Tunick, 1992). Nietzsche says ñwithout cruelty there is no festival: thus the longest and most ancient part of human history teaches $\ddot{i}$ and in punishment there is so much that is festive!ò (GM II: 6). The slave revolt, propelled by óessentimentô altered punishment from a cruel, severe, celebrated instinctual óvill to lifeôinto something that is now used to promote evilness and wrongness. The power that now punishes

\footnotetext{
${ }^{2}$ He translated the version of GM that I am using.
} 
understands punishment to be a means of upholding justice by meting out retribution, or of treating the sick, or of preventing crimeò (Tunick, 1992, p.22).

3. Nietzsche explicitly makes the point that the origins of the purposes and utilities for punishment cannot be inferred by the current state of punishment. He says that p̃purposes and utilities are only signs that a will to power has become master of something less powerful and imposed upon it the character of functioné (GM II: 12). Nietzsche is making a claim against other genealogists who posit purpose and utility as the origins of punishment. Purposes and utilities are guilelessly placed as the causa fiendi by other genealogists (GM II: 12). The custom of punishment is a ñcontinuous sign-chain of ever new interpretations and adaptations whose causes do not even have to be related but, on the contrary, in some cases succeed and alternate with one another in a purely chance fashionò(GM II: 12).

Placing purposes and utilities as the origins of punishment is bad genealogical work according to Nietzsche. We must first extrapolate the underlying psycho-historical origins which led to punishment. Nietzsche argues that understanding the origins of good, bad, and evil are the underlying causa fiendi of punishment. The creditor/debtor relationship in accordance with master/slave morality, and the subsequent slave revolt in morality, provides us the psychohistorical conditions needed for good, bad, and evil to arise, thus serving as the causa fiendi of punishment. The postcard from Nietzsche to Overbeck (see above p. 3) becomes helpful in bridging the gap between master/slave and creditor/debtor. While Nietzsche deals with these two issues separately in the GM, the postcard implies that we should see these two concepts as a unified account of the causa fiendi of punishment.

\section{Justifying Punishment and Sovereignty}


So far I have described the psycho-historical conditions from which Nietzsche explains the origins of morality and punishment $i ̈$ the master/slave and creditor/debtor relationship. Before the slave revolt, the masters enjoyed creating and determining their own values such as what was good and bad. Moreover, they enjoyed expulsing their will to power upon the slaves. During the slave revolt, the mastersôvaluations were reversed and revaluated by the slaves. The slaves, motivated by ressentiment, developed the bad conscience and introduced a new dichotomy of valuations ï namely good and evil. Good and evil were justified on the existence of the ñomniò god.

We saw how the pre-slave revolt masters enjoyed punishing their debtors as a óvill to lifeô but did not see debtors as guilty, evil, or sinful. Instead, their perceptions of debtors, who did not repay their debts, extended only to the infliction of harm. The masters recognized that every harm had its equivalent which prevented excessive and indeterminate punishing. Upon the arrival of good and evil, the slaves sought to inflict the bad conscience onto every debtor by participating in the rights of the masters via the imposition of guilt and shame etc. Guilt and shame are justified on the presupposition that every agent has deserts free-will. If actors have deserts free-will, then assumingly they can be said to deserve praise or blame, be deterred from certain acts, or be restored/taught to obey moral imperatives so as to avoid punishment. In this section, I shall make explicit Nietzscheôs views on agency, free-will, and the slavish justifications for punishment which modern man now adheres to.

In order to make sense of Nietzscheôs views on free-will and punishment, we should distinguish between two approaches to this issue. The first approach is a question of whether or not free will is intrinsically tied to questions of deserts i.e. does someone deserve to be punished for doing $X$ ? (Gemes, 2006). Furthermore, this approach is concerned with the question of 
whether or not somebody can act other than they did. For example, if person A is said to have a choice to do either $\mathrm{X}$ or $\mathrm{Y}$ and he chooses $\mathrm{X}$, then according to this approach, person A could have just as easily chosen $\mathrm{Y}$ instead of $\mathrm{X}$; person A could have chosen otherwise. Therefore, person A can be said to deserve a punishment or reward for choosing X over Y. Free will, according to the second approach, is intrinsically linked to agency i.e. what constitutes an action versus a mere doing (Gemes, 2006). For example, if person A chooses X over Y, then, according to this approach, we want to know what conditions made it such that person A choose $\mathrm{X}$ instead of $\mathrm{Y} \ddot{\mathrm{I}}$ if a choice was possible at all. The former implies that one can be held morally accountable, at least in the Judeo-Christian sense, for his actions because he has the free-will to choose to do otherwise. The latter implies that one cannot be held morally accountable, at least in the Judeo-Christian sense, because one does not have the freedom to choose to do otherwise. Nietzsche argues that ñyou are not sufficiently whole to have the right to make promises; you have no free-willò (Gemes, 2006, p.327) even though you are taught from a young age that you do. Instead, you ñare merely tossed about willy-nilly by a jumble of competing drives, and, hence, you cannot stand surety for what you promiseò(Gemes, 2006, p.327).

In almost all of Nietzscheôs philosophy he argues against deserts free-will but affirms agency free-will (Gemes, 2006). For example, in HAH Nietzsche says:

ñNow one finally discovers that this nature, too, cannot be accountable, inasmuch as it is altogether a necessary consequence and assembled from the elements and influence of things past and present: that is to say, that man can be made accountable for nothing, not for his nature, nor for his motives, nor for his actions, nor for the effects he produces. One has thereby attained to the knowledge that the history of the moral sensations is the history of an error, the error of accountability, which rests on the error of freedom of willò (HAH I: 39).

A few passages later Nietzsche says ñfor he who is punished does not deserve punishment; he is merely being employed as the means of henceforth deterring others from certain actions; 
likewise, he who is rewarded does not deserve this reward: for he could not have acted otherwise than he didò(HAH I: 105). Nietzsche argues that a system of punishments and rewards in which people are held as causal agents came as a result of the Christian slave revolt. According to Christian metaphysics, god gives humans the inherent free will to choose to either do ñgoodò or ñevil.ò Christianity teaches that human beings are free from the causal nexus of the empirical universe $\ddot{i}$ something that Nietzsche has come to loath. Every person has the intrinsic ability to freely choose whether or not to obey the universal moral imperatives established by god. The pot is sweetened by the reward of heaven if one chooses to be moral and the punishment of hell if one chooses to be immoral. The burden of moral responsibility is therefore completely bestowed upon the individual. This is the kind of existential beast promoted by the slaves which eventually carried the weight of day into modern times. Nietzsche despises this kind of faulty, speculative, metaphysical system because it is representative of the herd instinct and imposes an immoral morality. Instead, Nietzsche says that we should only attribute a kind of responsibility that goes with being effective, not causal, agents (Gemes, 2006).

A note must be made here regarding the difference between a system of punishments and rewards and a system of praise and blame. Nietzsche quite often assigns praise and blame to historical figures and his contemporaries such as Socrates, Jesus, Ree, Wagner etc. (Gemes, 2006). When Nietzsche praises or blames, he is assigning responsibility to people but only in a ñsense of being agency responsible, not in the sense of being deserts responsibleò (Gemes, 2006, p. 324). Thus, even though Nietzsche denies deserts free-will, this does not mean human beings are completely mollified from praise or blame because factually one does act; therefore, one may be characterized as praiseworthy or blameworthy. Nietzsche argues that since punishments and rewards are related to deserts agency, the imposition of a system of punishments and rewards is 
unwarranted because human beings are not causal agents but effective ones. Moreover, to punish or reward based on deserts free will is to affirm Christian slave morality which affirms metaphysical justifications. Nietzsche vehemently opposes such systems. He says ñn Christianity, neither morality nor religion comes in touch at all with reality. Nothing but imaginary causes (God, the soul, the ego, spirit, free-will ï or unfree will): nothing but imaginary effects (sin, redemption, grace, punishment, forgiveness of sins)ò(A: 15).

The culminating views that have been described up this point might suggest that Nietzsche thinks modern punishment practices should be abolished. The abolitionist reading seems to be in line with Nietzscheôs overall philosophical project $\ddot{i}$ to revaluate all values. I shall consider an interpretation of Nietzsche as an abolitionist thinker in the final section of this essay. However, before the abolitionist argument can be made we must answer some questions about modern justifications for punishment. Specifically, does retributive punishment effectively give one what he deserves? Does punishing people deter that person or others from committing similar crimes? Does educating and reuniting offenders with their victims in order to restore communal relationships work? Nietzsche has answers to these questions which I shall now make explicit.

Retributive punishment is justified on the grounds that punishing criminal offenders for their offenses is intrinsically good. Punishment is not a means to any other end i.e. crime reduction or rehabilitation of offenders; it is an end in and of itself (Reidy, 2007). Morality and behavior go hand in hand, therefore, the ñmorally culpable criminal offender deserves to suffer and to suffer punishment in particular, and it is therefore intrinsically good the she get what she deservesò (Reidy, 2007, p.170). According to this view, punishment is backwards looking and not concerned with what future implications a certain kind of punishment might have on either 
an individual or community. For Nietzsche, a retributive justification for punishment is reducible to the Christian morality of ressentiment. When one is punished because she deserves it, then the agent is presupposed to possess deserts free will. Deserts free will, according to Nietzsche, has metaphysical overtones. The case was made above that Nietzsche denies metaphysical claims and deserts free will. Therefore, he is against the idea that somebody deserves punishment because they could have acted otherwise.

Punishment can also be justified on instrumentalist or utilitarian grounds in which punishment is extrinsically justified. The central component to punishment practices is the extrinsic good it yields. For example, an instrumentalist might argue that punishment is necessary for deterring future crime. There are two kinds of deterrence $\ddot{i}$ specific and general. The former says that punishment is aimed at deterring the individual being punished from committing future crimes. The latter is aimed at deterring others from committing crimes. Punishment in this sense might be said to be future directed; however, Nietzsche sees deterrence as a backward looking justification because of its origins in the slave revolt.

Utilitarianism traditionally uses empirical data to demonstrate its claims. For example, if we are to justify mass incarceration on deterrence grounds, either specific or general, then we would have to produce evidence that mass incarceration actually deters future criminal acts. However, ñthe fact is that the empirical evidence regarding the different effects, general and specific, of punishment is mixed at besté recent studies suggest that when punishment deters, it does so only insofar as it unambiguously and immediately communicates to potential offenders severe social condemnationò (Reidy, 2007, p.162). Nietzsche might argue that since the empirical evidence does not support mass incarceration, then it should be done away with. However, the more potent and important objection Nietzsche might raise is against the entire set 
up of the instrumentalistôs view, regardless of whether people are actually deterred or not, because this justification for punishment focuses on using people as functionaries of morality. Turning people into functionaries of morality is a contradictory slavish idea that perpetuates the herd mentality and an immoral morality. The contradiction is when a society preaches the immoral behavior of using someone as a means to an end. However, that is exactly what an instrumentalist justification for punishment does $\ddot{i}$ namely using criminals to deter deviant behavior.

Punishment as a method of restoration is yet another example of punishment as a mere slave utility. The justification behind restorative justice is that criminals can be educated about their behavior, subsequently change their behavior, and make amends with those they have harmed. For example, we may incarcerate somebody for the purpose of sending them to classes in order to learn why their actions were deviant and unlawful, and how to avoid situations in the future that may lead to subsequent deviant behaviors. Moreover, we might educate inmates on how to become better citizens i.e. how to pay child support, pay taxes, and obtain gainful employment etc. Once the criminal is educated, he is encouraged to make amends with individual/s and the community he harmed. While the justification here is different than in deterrence or retributive theories, the underlying principles of why we punish remain the same and bear repeating: because people have deserts free will and can be held morally culpable for their actions; therefore, they can be punished or rewarded for said actions.

Do any of the above justifications for punishment actually aid in the reduction of deviant behavior or reduce recidivism? Nietzsche argues that they do not given Western cultures psycho-historicity. Firstly, the slave morality that now controls punishment practices is ill suited to wield this kind of power (Tunick, 1992). Punishment was originally used by the masters to 
celebrate life, to outwardly discharge their will to power, to vent their anger upon others, and to festively enjoy suffering. But now punishment is a tool used to impose obedience to slavish moral imperatives through guilt, shame, and pity. Slavish morality imposes internalization of the bad conscience in order to make culture more tame, moderated, Christianized, ónob-izedô and herd-like. According to slave morality, ñpunishment is supposed to possess the value of awakening the feeling of guilt in the guilty person; one seeks in it the actual instrumentum of the psychical reaction called the fŕad conscience,ò sting of conscienceò (GM II: 14). Therefore, punishment justified through retribution, deterrence, and/or restoration etc., will not be effective because punishment was only appropriately wielded by the masters (Tunick, 1992). Secondly, Nietzsche argues that punishment wielded by the slaves will not be effective because:

ñt is precisely among criminals and convicts that the sting of conscience is extremely rare; prisons and penitentiaries are not the kind of hotbed in which this species of gnawing worm is likely to flourish: all conscientious observers are agreed on that, in many cases unwillingly enough and contrary to their own inclinations. Generally speaking, punishment makes men hard and cold; it concentrates; it sharpens the feeling of alienation; it strengthens the power of resistanceò (GM II: 14).

All the above justifications for punishment share as their common denominator the idea that justice is being carried out albeit a justice of ressentiment. In order for there to be justice, at least in the sense described above, there has to be a system of law that holds people accountable for their actions and assumes that agents have deserts free will. According to Nietzsche, we do not possess deserts free will. Therefore, it may come as no surprise that Nietzscheô views on the kind of ñusticeò described above are nonsense and ultimately meaningless. He says ñjust and unjust exist, accordingly, only after the institution of the lawé To speak of just or unjust in itself is quite senseless, in itself, of course, no injury, assault, exploitation, destruction can be unjust, since life operates essentially, that is in its basic functions, through injury, assault, 
exploitation, destruction and simply cannot be thought of at all without this characterò (GM II:

$11)$.

The kind of justice sought after in the West is a kind of equal justice wherein everybody is supposed to receive equal treatment under the law. This means that regardless of social standing, ethnicity, race, sexual orientation, gender, political affiliation etc. everybody is entitled to receive equal treatment. If two people from two completely separate backgrounds commit the same infraction against the law, then they should both receive similar and equal punishments. For Nietzsche, the notion of equality among humans is óostile to lifeôand a óecret path to nothingnessô He says:

ñBehold, is this the hole of the tarantulaé There it comes willingly: welcome, tarantula! Your triangle and symbol sits black on your back; and I also know what sits in your soul. Revenge sits in your soul: wherever you bite, black scabs grow; your poison makes the soul whirl with revengeé you who make souls whirl, you preachers of equality. To me you are tarantulas, and secretly vengefulé Therefore, I tear at your webs, that your revenge may leap out from behind your word justice. For that man be delivered from revenge, that is for me the bridge to the highest hopeé The tarantulas, of course, would have it otherwise. ñWhat justice means to us is precisely that the world be filled with the storms of revengeò $i$ thus they speak to each other. ñWe shall wreak vengeance and abuse on all whose equals we are notò $\ddot{i}$ thus do the tarantula-hearts vow. ñAnd óvill to equalityôshall henceforth be the name for virtue; and against all that has power we want to raise our clamor!ò (TSZ, p. 100).

The tarantulas are the slaves and those óvhose equals they are notô are the masters. The successes of the slave revolt have made the masters equals with the slaves. They have spread the illness of ressentiment. Now punishment is associated with slavish ideas of revenge, justice, and equality. Moreover, Nietzsche thinks that most modern justifications for punishment like deterrence or restoration etc. are merely masks for revenge. The kind of justice that Nietzsche praised was that of the masters wherein ñeverything is dischargeable, everything must be dischargedò (GM II: 11). The modern slavish notion of justice is the antithesis to the master. 
Thus, the entire enterprise of Western jurisprudence is compromised by the successes of the tarantulas and their perpetuation of deserts free will, revenge, punishment, ressentiment, and the bad conscience. For Nietzsche, if modern culture in the West continues down this road, then eventually the ensuing demise of culture will spiral into nihilism.

At this point one may feel compelled to interject and ask: what does all this mean? Should we abandon our modern punishment practices and return to the punishment practices of the masters? If Nietzsche is correct in arguing that the purposes we give for punishment are mere slavish utilities meant to impose life-denying and ascetic morals in order to tame and domesticate man, then is there anything we can do to reverse the reversal and use punishment as a life affirming practice as it once was? These are good questions and there are readings to suggest that Nietzsche is calling us back to live the lives of masters (Tunick, 1992). Consider NietzscheQ̂ grandiose philosophical project which is to reevaluate all values. White argues that:

ñHis [Nietzscheô] genealogy is an attempt to force the will of millennia upon new tracks by recollecting all that was nonsense and accident in our history, and showing how it may be redeemed with the return of the master, or the sovereign individual, as the fulfillment of the individual life. In this way Nietzsche suggests that the slave may free himself from the cancer of ressentiment, for the will loses ñts ill-will against time,ò when, as a sovereign will, it finally becomes capable of embracing every stage of its accidental history as a necessary moment of its own self-appropriationò (White, 1994, p.74).

The sovereign individual is one ñwho has his own independent, protracted will and the right to make promises $\ddot{i}$ and in him a proud consciousness, quivering in every muscle, of what has at length been achieved and become flesh in him, a consciousness of his own power and freedom, a sensation of mankind come to completionò (GM II: 2). Nietzsche understands sovereignty to mean that one possesses the natural ability to have genuine agency and a good conscience. In Western modern culture, we have agency based on the bad conscience and 
slavish justifications ï namely we conceive of ourselves having free will and deserts agency. We deceive ourselves, individually and culturally, in believing we have genuine free agency, but, according to Nietzsche, we do not. We are driven by slavish herd notions of revenge, jealously, ressentiment, envy, guilt, shame etc. Whereas the sovereign individual is liberated from the chattels of the herd and comes to realize what it means to have genuine agency. But in order for the sovereign individual to arise there must be a revaluation of all values, and culture must reinvent itself which includes rethinking the entire enterprise of punishment and even law itself.

While Nietzscheôs optimism regarding the human condition is reflected in his revaluating all values project, there is a more problematic view that Nietzsche implies about punishment. He considers the possibility that there is no purpose or justification for punishment. He says:

ñhe cause of the origin of a thing and its eventual utility, its actual employment and place in a system of purposes, lie worlds apart; whatever exists, having somehow come into being, is again and again reinterpreted to new ends, taken over, transformed, and redirected by some power superior to ité However well one has understood the utility of any physiological organ (or of a legal institution, a social custom, political usage, a form in art or in a religious cult), this means nothing regarding its origin: however uncomfortable and disagreeable this may sound to old ears $\ddot{i}$ for one had always believed that to understand the demonstrable purpose, the utility of a thing, a form, or an institution, was also to understand the reason why it originated $i ̈$ the eye being made for seeing, the hand being made for graspingò (Tunick, 1992, p. 24).

Nietzsche is ñwarning us against mistakenly thinking that our conception of the value of a practice accounts for the origins of the practiceò (Tunick, 1992, p.25). He argues that humans are responsible for attributing the meaning and purpose into punishment and ignoring the historical context of the practice itself (Tunick, 1992). The origins of punishment do not provide the purposes or meaningfulness of punishment. Instead, we impose meanings and purposes into punishment in order to make punishment justified in any given historical situation. The justifications given in any historical context reflect the cultural psychology. Nietzsche lists 
multiple reasons why punishment may occur such as: means of rendering harmless, expulsion of a degenerate element, as a declaration of war, as recompense to the injured party for harm done, a kind of repayment for the advantages the criminal has enjoyed hitherto etc. (GM II: 13). This list is not exhaustive; however, it provides evidence for Nietzscheô argument that:

ñhe concept ñpunishmentô possesses in fact not one meaning but a whole synthesis of òmeaningsò. the previous history of punishment in general, the history of its employment for the most various purposes, finally crystallizes into a kind of unity that is hard to disentangle, hard to analyze and, as must be emphasized especially, totally indefinable. (Today is impossible to say for certain why people are really punished: all concepts in which an entire process is semiotically concentrated elude definition; only that which has no history is definableò (GM II: 13).

Nietzsche offers an indictment of the inclination to impose definitions onto a historically tangled and indefinable practice such as punishment. If we only have a óvhole synthesis of meaningsôand not just one meaning of punishment, then how can we ever arrive at the ñrueò meaning of punishment? Even though at certain times in history one element appears to overcome all other elements and mark the ñrueò meaning of punishment, Nietzsche argues that this is only an appearance (Tunick, 1992). We do not arrive at the ñrueò meaning of punishment because the historical unity of punishment cannot be disentangled. Therefore, for Nietzsche, there is no essence or ñrueòmeaning of punishment. All that can be said of punishment is that it exists and descriptions of various practices can be accounted for using various justifications. Nietzsche is thus challenging the entire historicity of punishment by claiming that since we cannot unearth a ñtrueò meaning of punishment, we must conclude that there is no justification or essential meaning for punishment. Therefore, in this light, the value of Nietzscheô genealogical method ñies, not in telling us the true purpose of punishment, but in helping us see that there is no true purposeò (Tunick, 1992, p.26). If there is no true purpose for punishing, either from a 
master, slave, or any other perspective, then does that mean that we should abolish punishment altogether?

\section{Nietzsche as an Abolitionist}

It is not completely clear that Nietzsche proposes the abolishment of punishment altogether. He admires the punishment practices of the masters because they indulged in their instincts. They celebrated and affirmed life through punishing, being cruel, and discharging their will upon others. This does not mean, though, that Nietzsche thinks we should abolish modern punishment altogether and revert back to punishing based on pure instinct. I suggested earlier that one may interpret Nietzsche this way. Indeed, Nietzsche might be calling us back to the mastersô mentality but only insofar as we eliminate the Christian morality of ressentiment and its baggage. Keep in mind that Nietzscheôs naturalism allows for the possibility that humans can psychologically mature into creatures that do not punish. Maturation of this kind is not suggestive of a slavish denial of instincts. Instead, maturing beyond the realm of taking ones deeds too seriously and accepting the human condition as essential is what Nietzsche has in mind. However, we cannot psychologically mature to the point of discharging harms because the slave revolt has taught us to use guilt, shame, dishonor, pity, disappointment etc. which keeps us stagnant in our development. However, it is clear from the passages mentioned above (especially see quoted text on p. 27-8) that Nietzsche is at least ready to abolish punishment insofar as it is a modern slavish tool used to spread Judeo-Christian morality. In other words, modern punishment practices ought to be eliminated from modern culture because our punishment practices are nothing more than Judeo-Christian condemnation. 
Slave justice is the worst kind because it simply demonstrates that humans are inherently bad and sinful. Thus Nietzsche says ño raise and transform the concept of justice ï or prove that the human action is necessarily unjustò (Ansell-Pearson, 1991, p. 9). Nietzsche regards the slave revolt in morality as a turning point in which humanity inherited its soul, free will, promise of eternal happiness, the ñomniò god, and all of the other life-denying attributes that makes humanity weary of itself. These attributes are justified by a faulty, speculative, and atrocious Christian metaphysics which Nietzsche has discarded as possessing any value. However, the disappointing fact, for Nietzsche, is that Christian metaphysics is the accepted and enduring value system of modernity. His explicitness in providing a scathing indictment of JudeoChristian morality and its implications is unshakable:

ñWhat defines me, what sets me apart from the whole rest of humanity is that I uncovered Christian moralityé I regard [Christian morality] as the greatest uncleanliness that humanity has on its conscience; as self-deception become instinctive; as a fundamental will not to see any event, any causality, any reality; as counterfeiting in psychologicis to the point of criminality. Blindness to Christianity is the crime par excellence $i \vec{i}$ the crime against lifeé Christian morality $\ddot{i}$ the most malignant form of the will to lie, the real Circe of humanity $\ddot{i}$ that which corrupted humanity. It is not error as error that horrifies me at this sight $і ̈$ not the lack, for thousands of years, of ñgood will,ò discipline, decency, courage in matters of the spirit, revealed by its victory: it is the lack of nature, it is the utterly gruesome fact that anitnature itself received the highest honors as morality and was fixed over humanity as law and categorical imperative. To blunder to such an extent, not as individuals, not as people, but as humanity!ò(EH IV: 7).

It is important to keep our focus on what Nietzsche is doing in the GM. He is offering a psycho-historical-genealogical perspective of the origins of good and bad contra good and evil. The latter valuations arrived as a result of the slave revolt in morality beginning with the Jews and coming to fruition via Christianity. Nietzsche has claimed that the slave revolt has been victorious and Judeo-Christian values have survived into modernity. The language from the passage above (as well as elsewhere) ought to provide a clear understanding of Nietzscheôs 
feelings against the continuance of Christian morality. Therefore, to abolish Christian morality means to abolish all of the baggage that accompanies it, which would extend to modern punishment practices.

To corroborate this point even further, I should mention one of the most famous declarations by Nietzsche ï ñGod is dead.ò The god that Nietzsche is referring to is the JudeoChristian conception. For Nietzsche, the death of god means that ñthe supreme values of European thinking $i ̈$ in particular, the values of an absolute Truth, Goodness, and Beauty, the unity of which has been thought in theologico-philosophical concept of God ï have lost their valueò (Stegmaier, 2006, p. 20). Nietzsche says ñGod is dead. God remains dead. And we have killed himò (GS: 125). In order to fully understand what Nietzsche means we cannot overlook the historical conditions which prompted Nietzsche to coin this phrase. Kaufmann explains that:

ñspeculative philosophy seemed to have spent itself in the ambitious systems of Schelling, Hegel, and Schopenhauer; and Darwinôs doctrines were conquering the world. At the same time, Prussian arms established Germanyố political supremacy on the continent; science and technology were making the most spectacular advances; and optimism was common. Nietzsche, however, stigmatized this age as nihilisticò (Kaufmann, 1974, p. 96).

So with the advancements of technology and science and metaphysics being spent, Nietzsche sees himself positioned in a pivotal point in history. He observes that god is beginning to play less and less of a role in culture. If god dies, then what does that mean for all the things that god was responsible for maintaining especially concerning morality? Nietzsche thinks that the values and morals attached to the conception of the Judeo-Christian god ought to go away since god is dead. However, even though god is playing less of a role, the morals and values which accompany god are still being practiced. In other words, Nietzsche observes culture as killing god but keeping the 
morality. Therefore, a revaluation of values should take place in order to undo the damage of Christianity and usher in a life-affirming morality.

The abolishment of Christian morality, and subsequently a majority of modern punishment practices, is not a far reaching notion considering Nietzscheôs ultimate philosophical goal was to revaluate all values. Nietzsche says that ñan attempt at the reverse would in itself be possible $і ̈$ but who is strong enough for it?ò (GM II: 24). Who is strong enough to stand up to two-thousand years of slave ressentiment, shed his bad conscience, and reverse the damage caused by the slave revolt? A revaluation means throwing out the current system of values and replacing it with something completely different. To be more specific, a revaluation means eradicating Christian morality and replacing it with a naturalistic one. I do not mean to imply that Nietzsche thinks that Christian morality is responsible for the entire enterprise of modern punishment practices. However, Christianity is responsible for ñpromoting an outlook on human behavior that focuses on guilt, [it] fosters the spirit of retaliation that institutions of punishment traditionally reflectò (Higgins, 1987, p.37). The imposition and perpetuation of deserts free will, guilt, shame, dishonor, and sin in oneôs life is the bridge that intrinsically links most of modern punishment practices to traditional Judeo-Christian morality. Based on Nietzscheôs strong objections to this morality, his genealogical perspective on the origins of good and evil, his critique of modernity including punishment, and his project to revaluate all values, I maintain that it would be, at the very least, difficult to not draw the conclusion that Nietzsche is an abolitionist toward the majority of modern punishment practices.

A note must be made here about two obvious objections to this account of Nietzsche as an abolitionist and reconstructionist. Firstly, eradicating Christian morality and its baggage from modern culture seems to be a lofty goal and practically impossible. This project borderlines on a 
kind of idealism wherein Nietzsche is imagining an unlikely achievable best case scenario. Such a practically impossible goal cannot be taken as anything but an ideal state of affairs. Therefore, we should not attempt a revaluation of values, but instead tweak the existing value paradigm so that we might slightly move away from Christian morality. Secondly, even if we did revaluate all values, how do we know that we would be better off than we are now?

Nietzscheô genealogical method comes in handy when addressing both of these concerns. In response to the first objection one might argue that humanity, according to Nietzsche, flourished in the pre-Christian slave revolt era. The downtrodden people or slaves revaluated all values once before by using the naiveté of the masters against them. The slaves erected the ideal ñomniò god and subsequently introduced humanity as inherently sinful. The masters drank the Kool-Aid and adopted the slave mentality. Since a revaluation of values has been successfully carried out before, it is not inconceivable that another revaluation of values occurs once more. The Judeo-Christian world view is nothing more than ideal in and of itself; therefore, if this ideal is constantly in the process of being realized and actualized, then why is it inconceivable that Nietzscheôs ideal not be realized and actualized. Nietzsche argues that:

ñWe modern men are the heirs of the conscience-vivisection and self-torture of millennia: this is what we have practiced longest, it is our distinctive art perhaps, and in any case our subtlety in which we have acquired a refined taste. Man has all too long had an ñevil eyeò for his natural inclinations, so that they have finally become inseparable from his ñbad conscienceòò (GM II: 24).

It is not that we are unable to revaluate all values. We are just so deeply entrenched in slave morality and complaisant with ourselves that it is unthinkable that anyone or any cultural movement could have the strength to overcome our herd instincts and revalue all values. But Nietzsche remains optimistic that we are capable and one day the revaluation will happen. 
However, the question still remains: who is strong enough to begin this process and see it through?

In regards to the second objection, I appeal to Nietzschê̂ GM once again:

ñBut have you ever asked yourselves sufficiently how much the erection of every ideal on earth has cost? How much reality has had to be misunderstood and slandered, how many lies have had to be sanctified, how many consciences disturbed, how much ñGodò sacrificed every time? If a temple is to be erected a temple must be destroyed: that is the law $\ddot{i}$ let anyone who can show me a case in which it is not fulfilled!ò(GM II: 24).

If we are to heed Nietzscheôs direction to revaluate all values and erect a new temple, then we must destroy the current paradigm. Nietzsche has pleaded his case for abolishing JudeoChristian morality. The critic who objects to Nietzsche on the grounds that we do not know if we would be better off with a new paradigm might say ñf we destroy the temple that houses us, we will be homelessò (Tunick, 1992, p.27). This might be true; however, the burden then rests on the critic to demonstrate how the temple we currently reside in is better than none or better than the one we might reconstruct through a revaluation (Tunick, 1992).

\section{Conclusion}

This essay has been intended to demonstrate and make explicit Nietzscheôs views on punishment. I have attempted to make clear Nietzscheôs thought extending from the origins of punishment to the abolishment of punishment. Nietzsche is a difficult philosopher to clarify because he did not engage in the kind of traditional analytic style to which Western philosophy is accustomed. He placed himself in contradistinction with systematic philosophers such as Plato or Kant specifically because he believed their philosophies were too systematized. While his rebellion is admirable and philosophically intriguing, it makes it difficult to follow his thought in a linear argumentative fashion like one might find in any one of Kant $\hat{Q}$ three Critiques. 
Nietzscheô style, therefore, might be susceptible to being misunderstood or have gaps in scholarship. I pointed out one these gaps in that Nietzscheôs views specifically on punishment have been overlooked. Although concepts such as the master/slave relationship, ressentiment, the bad conscience etc. have been independently paid a significant amount of scholarly attention, there exists a gap between these concepts and Nietzscheôs views on punishment. Therefore, the most I hope to have accomplished is to have shed light on the gap in the existing scholarship and offer one perspective on how to fill it. 


\section{References}

Ansell-Pearson, K. (1991). Translations from Nietzschê̂ Nachlass 1881-1884. The Journal of Nietzsche Studies. 1 (5-14).

Chilton, B. S. (2001). Criticizing postmodern criminal justice theory at its root: Nietzscheôs justice theory. The Justice Professional, 14 (79-93).

Gemes, K., \& Janaway, C. (2006). Nietzsche on free will, autonomy and the sovereign individual. Proceedings of the Aristotelian Society, Supplementary Volumes, 80 (321$357)$.

Higgins, K. M. (1987). Nietzsche’s Zarathustra. Philadelphia, PA: Temple University Press.

Hockenbury, D. H., \& Hockenbury, S. E. (2006). Psychology (4th ed.). New York, NY: Worth Publishing.

Janaway, C. (2007). Beyond selflessness: Reading Nietzsche's Genealogy. Oxford, NY: Oxford University Press Inc.

Kaufmann, W. (1974). Nietzsche Philosopher, Psychologist, Antichrist. Princeton: Princeton University Press.

Nietzsche, F. (1968). The Anti-Christ. (R. J. Hollingdale Trans.). New York, NY. Penguin Putnam Inc. (Original work published 1895)

Nietzsche, F. (2000). Beyond good and evil. (W. Kaufmann Trans.). New York, NY. The Modern Library. (Original work published 1886) 
Nietzsche, F. (1996). Human, all too human: A book for free spirits. (R. J. Hollingdale Trans.). Cambridge, NY: Cambridge University Press. (Original work published 1878)

Nietzsche, F. (1967). On the genealogy of morals. (W. Kaufmann \& R. J. Hollingdale Trans.). New York, NY. Random House Inc. (Original work published 1887)

Nietzsche, F. (1974). The gay science. (W. Kaufmann Trans.) New York: NY. Random House Inc. (Original work published 1882)

Nietzsche, F. (1995). Thus spoke Zarathustra. (W. Kaufmann Trans.) New York: NY, Random House Inc. (Original work Published 1883)

Reidy, D. A. (2007). On the philosophy of law. Belmont, CA: Thomson Wadsworth Corporation.

Risse, M. (2001) The second treatise in on the genealogy of morality: Nietzsche on the origin of the bad conscious. European Journal of Philosophy, 9 (1) (55-81).

Risse, M. (2005). On god and guilt: A reply to Aaron Ridley. The Journal of Nietzsche Studies, 29 (46-53).

Schacht, R. (2012). Nietzscheôs naturalism. The Journal of Nietzsche Studies, 43 (185-212).

Stegmaier, W. (2006). Nietzscheôs Doctrines, Nietzscheôs signs. The Journal of Nietzsche Studies, 31 (20-41). Doi: 10.1353/nie.2006.0011

Tunick, M. (1992). Punishment: Theory and practice. Berkeley and Los Angeles, CA: University of California Press. 
White, R. (1994). The return of the master an interpretation of Nietzscheô genealogy of morals. In R. Schacht (Ed.), Nietzsche, Genealogy, Morality: Essays on Nietzsche's On The Genealogy of Morals (pp. 63-75). Berkeley, Los Angeles, and London: University of California Press. 